\title{
Critical periods and parameters of growth of beet at drop irrigation in Southern Steppe
}

\author{
V. Vasiuta, candidate of agricultural sciences \\ Institute of water problems and land-reclamation of NAAS
}

The purpose. To determine critical periods of growth of beet at drop irrigation, to determine the degree of variability of productivity at change of parameters of growth in critical phases using B. Gomperts function. Methods. Field, statistical. Results. Speed of increase in crude mass of beet without fertilization decreases for $50,6 \%$, duration of critical period of growth increases for 0,9 day, productivity of root crops decreases for $46,9 \%$ in comparison with variant N90P60K135. Direct correlation link $(R=0,99)$ between variability of parameters of growth in critical points and productivity of root crops is revealed. Conclusions. Modelling of growth of beet using B. Gomperts function and its analysis allow determining parameters of growth in critical points at different factors of influence, and also determining their optimum ratio.

Key words: critical periods, critical points, Gomperts function, growth rate, acceleration of growth.

Problem statement. The main task of vegetable growing in market conditions is the intensification of production, aimed at increasing productivity, obtaining quality products, rational use of resources to minimize the negative impact on the environment. The yield in the end is the result of biological processes of different nature, the intensity of which is determined by the action and interaction of factors during the vegetation period of plants. As it is known, the violation of optimal conditions of cultivation, in critical periods of plant growth, leads to a decrease in their productivity, and the establishment of growth parameters in these phases, under the influence of regulatory factors, is solved on the basis of the analysis of growth functions [1].

This direction of research on drip irrigation, taking into account its distribution in the southern region, is a particularly urgent task, since it allows one to determine the level of variability of plant yields for changes in growth parameters in critical phases, under the influence of regulatory factors, and, accordingly, to determine their optimal ratio.

The state of studying the problem. The analysis of publications shows that in order to achieve high productivity, it is very important to maintain optimal conditions of cultivation during critical growth periods, since their violation causes loss of the share of the crop [2-5]. Determination of anatomical, morphological, physiological and biochemical aspects of growth at the time of critical points reaching plants provides a comparison of the obtained parameters, allows us to more fully disclose the essence of growth processes, establishing the beginning, end, duration of critical growth periods and a number of other indicators for taking into account the influence of regulatory factors [6]. One of the areas of research in growth processes is their modeling of growth functions [8,9], which allows analytically to determine critical periods. In irrigated vegetable growing, the concept of critical periods is considered mainly in the context of violation of optimal conditions for the maintenance of plants with moisture. However, for the creation of optimal conditions for the water regime of the soil, other factors act as carriers of the variability of growth processes, which definitely affects the productivity of plants. Literary sources indicate that the definition of the influence of various factors in critical periods is an important task, but this area of research on drip irrigation, in the southern region, is not given enough attention.

Methods. The purpose of our research was to determine the critical periods of the growth of the table beet for drip irrigation on the basis of the growth model analysis identified by the Benjamin Gompertz function and to determine the degree of variability of the yield due to the instability of the growth parameters during critical periods and the influence of the regulatory factors. The simulation of seedling beet planting processes was carried out according to the method [6] on the basis of experimental data of field experiments 2008-2010 carried out in accordance with the methodology [9-11] at the Institute of Irrigated Agriculture of NAAS of Ukraine.

Results. One of the main indicators of plant productivity is their mass, which, according to experimental data, has a different degree of dependence on the investigated factors of influence, and, accordingly, varies according to the intensity of growth processes. Determination of critical periods and 
growth parameters of modeling of plant growth processes was carried out by Benjamin Gompertz function:

$$
y=\frac{A}{10^{10^{a+b x}}},
$$

where $y$ - is the theoretical yield of crude mass, $\mathrm{t} / \mathrm{ha} ; A$ - is the difference between the upper and lower asymptotes of the growth curve (crude mass of plants), $\mathrm{t} / \mathrm{ha} ; \mathrm{x}$ - duration of the period from the beginning of growth, days; $a$ and $b$ - are constants that determine the slope and the points of the overlap of the growth curve.

The estimation of the approximation of the crude mass of beet plant plants for the investigated factors by the Gompertz function by criterion $\chi^{2}\left(\chi^{2}=0,09<\chi_{\mathrm{st}}{ }^{2}=3,841\right)$ showed that the theoretical indices at $5 \%$ level of reliability do not differ significantly from the experimental data, and, accordingly, the determination of critical periods and growth parameters for this function is permissible. The solution of the Gompertz equation allowed the obtained theoretical curves for the accumulation of crude mass of beet table plants by the investigated factors of influence (Fig. 1).

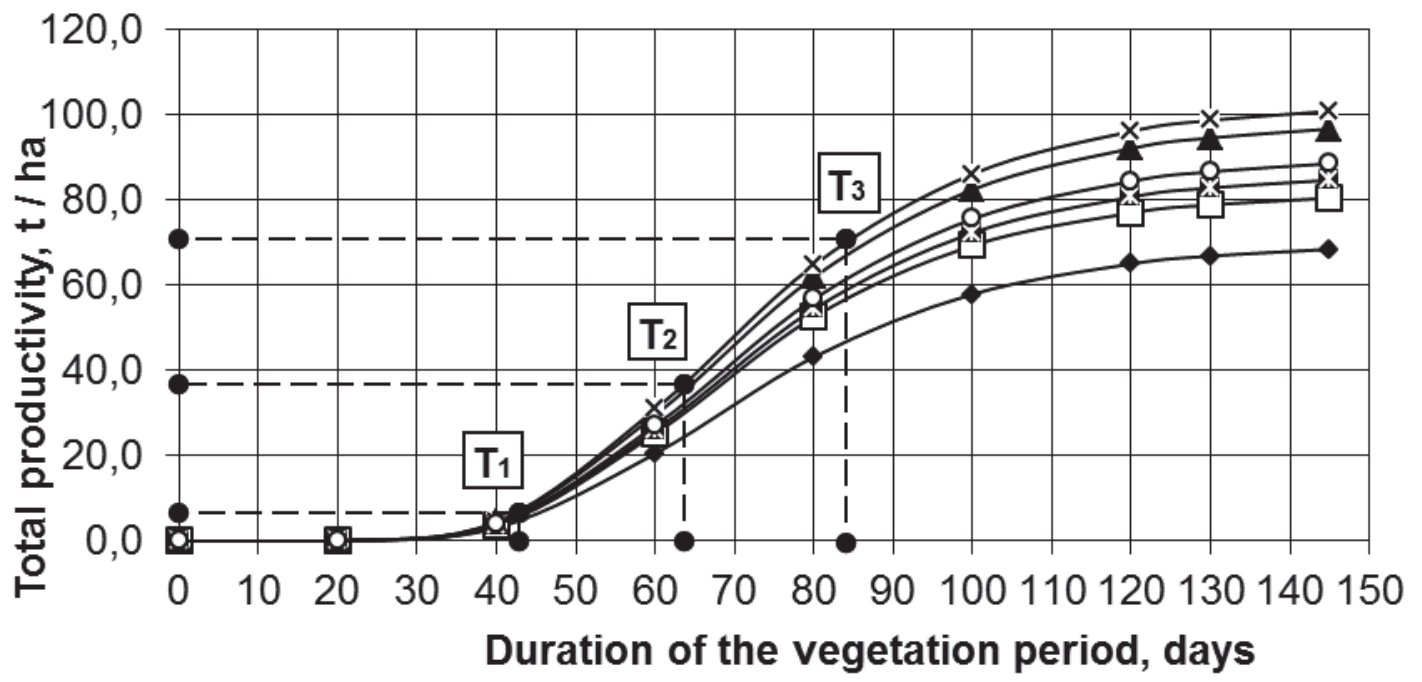

\begin{tabular}{|lll|}
\hline$\rightarrow-N o$ fertilizer & $-\square-\mathrm{P} 60$ & $\rightarrow$ N90P60K40 \\
$-\times-$ N90P60K135 & $\rightarrow-$ Local introduction & - - Fertigation \\
\hline
\end{tabular}

Figure 1. Dynamics of the accumulation of crude mass of beet plants for different feeding conditions of plants.

It is known that growth curves are characterized by periods, in which the intensity of growth processes varies from slow to accelerated, reaches a maximum and slows down. Thus, the growth curves have three distinct points of inflection: $T_{1}$ is the phase of increasing the growth rate, $T_{2}$ is the phase of the maximum growth rate, and $T_{3}$ is the phase of growth retardation. Points $T_{1}, T_{2}, T_{3}$ characterize the turning points of the growth process, are called critical points of growth [6].

Investigation of the growth function for various factors of influence revealed that the phase of intensive growth of growth rate (the first critical growth point - $T_{1}$ ), begins approximately 43.6 days from the beginning of the vegetation. The difference in the duration of the period does not exceed 0.02 days, proving that it does not depend on the investigated factors. The analysis of the influence of the investigated factors on the growth rate at the first critical point shows that the fertigation contributes to its growth by $4.4 \%$. Similarly, the growth rate of the raw mass of plants increases with a decrease in the feeding area from 250 to $175 \mathrm{~cm}^{2}$, which is explained by the greater number of plants per unit area in the second case. However, the greatest fluctuations in the growth rate of crude mass cause fertilizers (Fig. 2). 


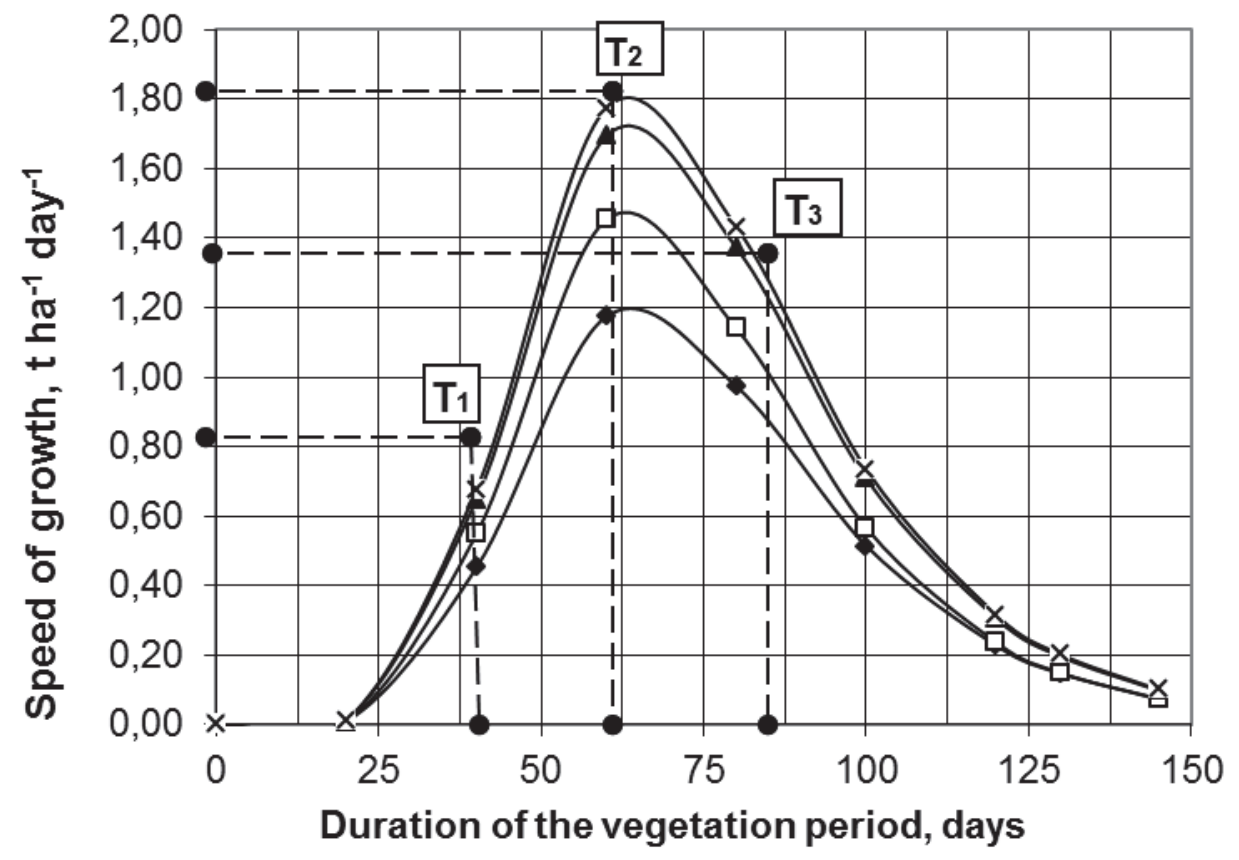

$\rightarrow$-No fertilizer $\rightarrow \square-P 60 ~ \multimap-N 90 P 60 K 40 \quad-\times-N 90 P 60 K 135$

Figure 2. Dynamics of the growth rate of crude mass of beet red for different feeding conditions of plants.

Thus, the introduction of phosphorus by the norm $\mathrm{P}_{60}$ contributes to it growth by $22.6 \%$, and fertilizers by the norm $\mathrm{N}_{90} \mathrm{P}_{60} \mathrm{~K}_{40}$ and $\mathrm{N}_{90} \mathrm{P}_{60} \mathrm{~K}_{135}$ on 43.6 and $50.3 \%$, respectively, compared with the option where no fertilizers were introduced. The estimate of the acceleration of growth at the first critical point $\left(T_{1}\right)$ shows that the maximum - 0.069 t/ha per day, it reaches the version $\mathrm{N}_{90} \mathrm{P}_{60} \mathrm{~K}_{135}$, which is $5.1-53.4 \%$ higher than in other variants (Fig. 3).

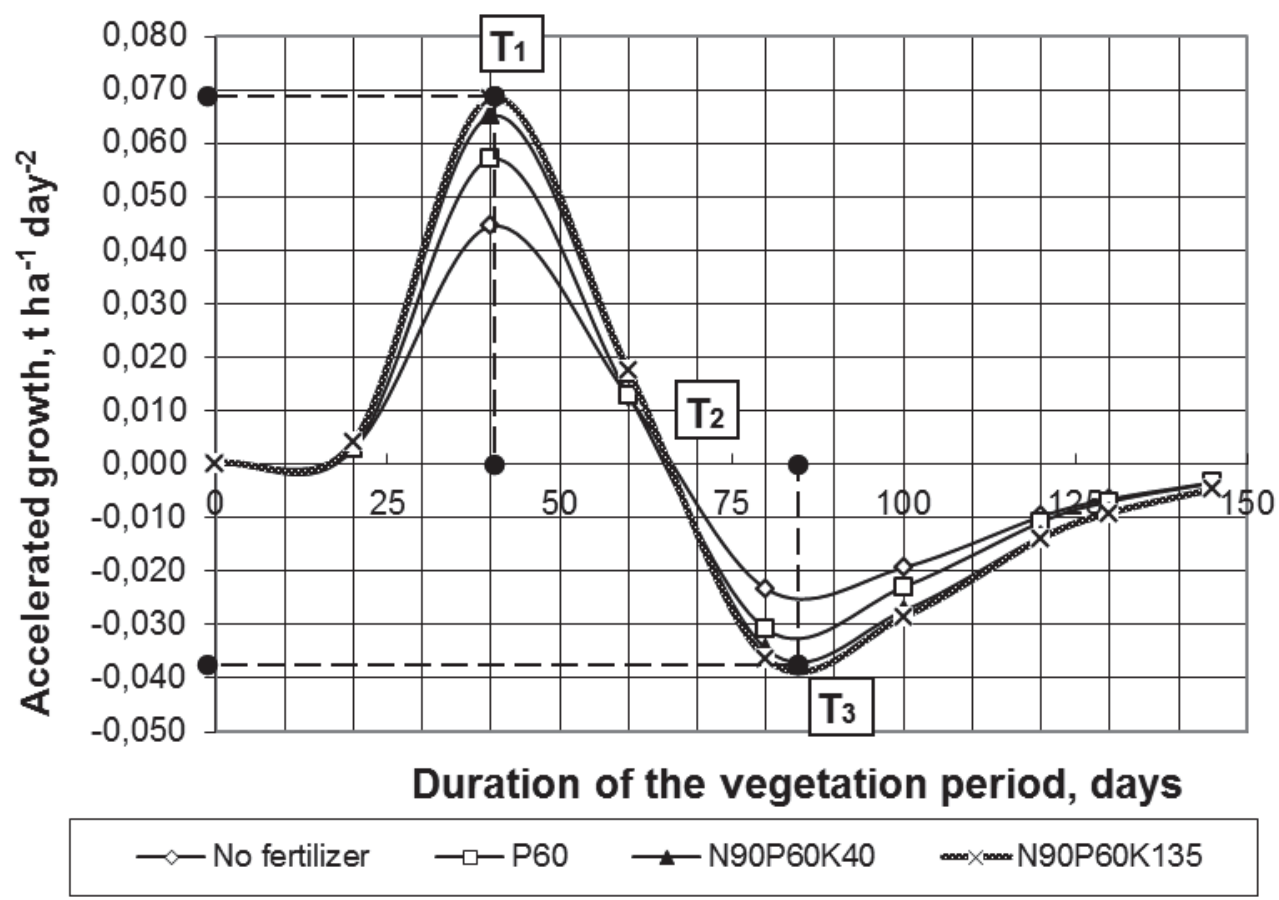

Figure 3. Accelerating the growth of the raw mass of beets during critical periods under different feeding conditions of plants 
From the investigated factors, the smallest amount of growth acceleration depends on the way fertilizer and plant nutrition area. The difference between the maximum and the minimum, for these cases, does not exceed $4.4 \%$. Studies of the growth function revealed that for each of the factors of influence of acceleration growth reaches the largest value in a period when the growth rate is not maximal.

Analysis of the growth rate at the critical point $-T_{2}$ shows that the maximum - $1.81 \mathrm{t} / \mathrm{ha}$ per day, it reaches through 63,9 days from the beginning of the vegetation for fertilizing the norm $\mathrm{N}_{90} \mathrm{P}_{60} \mathrm{~K}_{135}$, the minimum - 1.2, after 64,4 days. As you can see, the $\mathrm{N}_{90} \mathrm{P}_{60} \mathrm{~K}_{135}$ provides not only the maximum growth rate of the mass of the plant, but also reduces the duration of the critical period by 0.5 days, compared with the control variant, which is a sign of higher intensity of growth processes. Estimation of growth parameters at the second critical point $\left(T_{2}\right)$ shows that for each factor, which studied the maximum growth rate reaches zero acceleration, thereby indicating the transition of growth processes from the intensive phase of growth to the phase of growth retardation.

Estimating the speed and acceleration of growth at the critical point - $T_{3}$ it should be noted that the maximum speed - 1.28 t/ha per day provides the fertilizer rate $\mathrm{N}_{90} \mathrm{P}_{60} \mathrm{~K}_{135}$ for the most negative acceleration, which is observed at 84.2 days of vegetation. Conversely, the minimum growth rate is observed at a minimum negative acceleration value of 85.1 days of vegetation on a variant without fertilizers. Apparently, due to the growth of growth rate when fertilizing with the norm $\mathrm{N}_{90} \mathrm{P}_{60} \mathrm{~K}_{135}$ the duration of the critical period decreases on 0.9 days. Comparison of the growth rate and the duration of critical periods in other plant nutrition regimes show that the reduction of fertilizer rates in comparison with the $\mathrm{N}_{90} \mathrm{P}_{60} \mathrm{~K}_{135}$ in critical growth phases reduces the speed and increases the duration of the critical period.

It has been established that the duration of the critical period of growth over the investigated factors of influence is within the range of $40.4-41.3$ days. The estimation of the difference in the duration of critical periods for $\mathrm{t}$ - the criterion has shown that it is significantly higher only in comparison with the option without fertilization $\left(t_{f}=3.576>t_{s t .}=3.18\right)$. In all other cases, the difference lies within the limits of random oscillations for the accepted level of significance.

According to the results of the analysis, there is a direct correlation connection $(R=0.99)$ between the variability of growth parameters at critical periods $-T_{1}, T_{2}, T_{3}$ and yield of root crops of beet. The estimation of the influence of the variability of the growth rate at critical points on the yield of root crops shows that in the absence of fertilization, the growth rate is reduced by $50.6 \%$, which ultimately contributes to a decrease in yields by $46.9 \%$ compared to the fertilized norm of the $\mathrm{N}_{90} \mathrm{P}_{60} \mathrm{~K}_{135}$ variant. The analysis of the reaction of plants to the introduction of different standards of fertilizers shows that, for example, for the introduction of $\mathrm{N}_{90} \mathrm{P}_{60} \mathrm{~K}_{40}$ and $\mathrm{N}_{90} \mathrm{P}_{60} \mathrm{~K}_{135}$, the difference in growth rate during critical periods is the reason for reducing the yield level for less potassium by $4 \%$. The obtained determination coefficients show that in $98 \%$ of the cases, the transformation of the yield of root crops of beet is due to the change in the growth rate of the raw mass of plants in critical points of growth.

\section{Conclusions.}

Simulation of the growth of beetroot red by the Benjamin Gompertz function with a sufficient degree of reliability defines the production process for drip irrigation $\left(\chi^{2}=0,09<\chi_{\mathrm{st}}{ }^{2}=3,841\right)$. Studies of the growth function have found that the first critical growth point is due to drop irrigation - $T_{1}$ occurs 43.6 days after the beginning of vegetation, regardless of the factors of influence. The maximum growth rate is observed at the second critical point $\left(\mathrm{T}_{2}\right)$ for fertilizing with the norm $\mathrm{N}_{90} \mathrm{P}_{60} \mathrm{~K}_{135}$ through 63.9 days since the beginning of vegetation for zero growth acceleration, which confirms the transition from the phase of intensive growth to the phase of inhibition of growth processes and is confirmed by the maximum negative growth acceleration in critical point - $T_{3}$. The greatest duration of the critical period is observed in the variants without fertilizers -41.3 days, which is 0.9 days more than the fertilization rate $\mathrm{N}_{90} \mathrm{P}_{60} \mathrm{~K}_{135}$. The research establishes a close relationship between the growth rate of the mass of plants in the critical phases of growth and yield, which showed that the rate of fertilizers in $98 \%$ of cases affects the intensity of growth parameters in critical periods and, accordingly, is the determining factor for the variability of yield.

\section{Bibliography}

1. Tursun N. Critical period for weed control in leek (Allium porrum L.) / N. Tursun, B. Bükün, S.C. Karacan et al. // Hort Science. - 2007. - V. 42. - №. 1. - P. 106-109. 
2. Patron P.I. Kompleksnoe deystvie agropriemov v ovoschevodstve / P.I. Patron; otv. red. professor M.V. Alekseev.- Kishinev: Shtiintsa, 1981.- 284 p.

3. Fontes, P. C. R. Tomato yield and potassium concentrations in soil and in plant petioles as affected by potassium fertirrigation / Fontes, P. C. R., Sampaio, R. A., \& Mantovani, E. C //Pesquisa Agropecuária Brasileira. - 2000. - V. 35. - №. 3. - P. 575-580.

4. Chen $\mathrm{C}$. Application of growth models to evaluate the microenvironmental conditions using tissue culture plantlets of Phalaenopsis Sogo Yukidian 'V3'/ C. Chen //Scientia Horticulturae. - 2015. - V. 191. P. 25-30.

5. Tei F., Scaife A., Aikman D. P. Growth of lettuce, onion, and red beet. 1. Growth analysis, light interception, and radiation use efficiency / Tei F., Scaife A., Aikman D. P // Annals of Botany. - 1996. - V. 78. - №. 5. - P. 633-643.

6. Shmidt V.M. Matematicheskie metodyi v botanike: ucheb. posobie / V.M. Shmidt. - L.: Izd-vo Leningr. un-ta., 1984. - $288 \mathrm{p}$.

7. Wardhani, W. S. Describing the height growth of corn using logistic and Gompertz model Agrivita / W. S. Wardhani, P.Kusumastuti. - 2013, V. 35.-№ 3. P. 237-241.

8. Shi P. J. Capture the time when plants reach their maximum body size by using the beta sigmoid growth equation / P. J. Shi, , L.Chen, C. Hui, H. D. Grissino-Mayer //Ecological Modelling. - 2016. - V. 320. - P. 177-181.

9. Metodyka pol'ovykh i laboratornykh doslidzhen' na zroshuvanykh zemlyakh: naukovo-metodychne vydannya / za redaktsiyeyu R.A. Vozhehovoyi - IZZ NAAN, Kherson: Hrin' D.S., 2014. - 286 s.

10. Metodychni rekomendatsiyi z provedennya pol'ovykh doslidzhen' za kraplynnoho zroshennya /za red. M.I. Romashchenka, A.P. Shatkovs'koho, L.H. Usatoyi.- IVPiM NAAN Ukrayiny, 2014.- 44 s.

11. Metodyka doslidnoyi spravy $v$ ovochivnytstvi i bashtannytstvi / za redaktsiyeyu H.L. Bondarenka, K.I. Yakovenka. Kh.: Osnova, 2001.- 369 s. 